\title{
Characterization of BoHV-5 field strains circulation and report of transient specific subtype of bovine herpesvirus 5 in Argentina
}

\author{
Silvina S Maidana ${ }^{1}$, María F Ladelfa ${ }^{1,3}$, Sandra E Pérez ${ }^{3,5}$, Patricia M Lomónaco ${ }^{1}$, María P Del Médico Zajac', \\ Anselmo Odeón', Javier Blanco Viera', Gustavo Combessies ${ }^{4}$, Norberto Fondevila', María Palacios ${ }^{1}$, Julien Thiry², \\ Benoit Muylkens², Etienne Thiry², Sonia A Romera ${ }^{1,3^{*}}$
}

\begin{abstract}
Background: Bovine herpesvirus 5 (BoHV-5) is a member of the subfamily Alphaherpesvirinae responsible for meningo-encephalitis in young cattle. The first case of bovine meningo-encephalitis associated with a herpesvirus infection was reported in Australia. The current geographical distribution of BoHV-5 infection is mainly restricted to South America, especially Brazil and Argentina. Outbreaks of BoHV-5 are regularly observed in Argentina suggesting the circulation of the virus in the bovine population.

Results: Seventeen field strains of BoHV-5 isolated from 1984 to now were confirmed by differential PCR and subjected to restriction endonuclease analysis (REA). Viral DNA was cleaved with BstEll which allows the differentiation among subtypes $a, b$ and non $a$, non b. According to the REA with BstEll, only one field strain showed a pattern similar to the Argentinean A663 strain (prototype of BoHV-5b). All other isolates showed a clear pattern similar to the Australian N569 strain (prototype of BoHV-5a) consistent with the subtypes observed in Brazil, the other South-American country where BoHV-5 is known to be prevalent. The genomic region of subtype b responsible for the distinct pattern was determined and amplified by PCR; specifically a point mutation was identified in glycoprotein B gene, on the BstEll restriction site, which generates the profile specific of BoHV-5b.

Conclusions: This is the first report of circulation of BoHV-5a in Argentina as the prevailing subtype. Therefore the circulation of BoHV-5b was restricted to a few years in Argentina, speculating that this subtype was not able to be maintained in the bovine population. The mutation in the gB gene is associated with the difference in the restriction patterns between subtypes "a" and "b".
\end{abstract}

\section{Background}

Bovine herpesviruses 1 (BoHV-1) and 5 (BoHV-5) are closely related alphaherpesviruses infecting cattle $[1,2]$. The major difference between BoHV-5 and BoHV-1 is the distinct ability of the former to cause neurological disease in cattle $[3,4]$. In a natural infection via the respiratory tract, BoHV-1 and BoHV-5 replicate similarly in the nasal mucosa but they differ in their neuroinvasiveness $[5,6]$. BoHV-1 neuroinvasion usually does not go further than the first order neuron located in the

\footnotetext{
* Correspondence: aromera@cnia.inta.gov.ar

'Virology Institute, Veterinary and Agricultural Science Research Centre (CICVyA), National Institute of Agricultural Technology (INTA), N. Repetto y Los Reseros S/N, CC25 (B1712WAA), Castelar, Buenos Aires, Argentina Full list of author information is available at the end of the article
}

trigeminal ganglia, where the latent infection is established, whereas BoHV-5 is able to infect different regions of the brain [7-9].

The BoHV-5 genome is 137,821 base pairs (bp) long and is approximately 2,000 bp longer than the BoHV-1 genome, with a $\mathrm{G}+\mathrm{C}$ base composition of $75 \%[1,6]$. These viruses exhibit an average of $82 \%$ amino acid identity amongst different proteins. The most similar proteins ( $\geq 95 \%$ amino acid identity) are those involved in viral DNA replication and processing of virion proteins $[1,6]$.

Because of the great similarity between BoHV-1 and BoHV-5, the differentiation by conventional techniques such as viral isolation, immunofluorescence and neutralization test is difficult and has implications for the diagnosis as well as for BoHV-1 vaccination and eradication

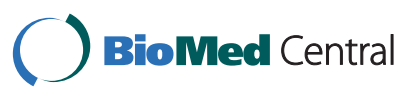


programs $[10,11]$. However, these viruses exhibit some important genetic and immunogenic differences, which would explain their pathogenic and epidemiological characteristics $[4,12,13]$. BoHV-5 is the causal agent of meningo-encephalitis; a condition of low morbidity and high lethality. It usually affects cattle up to 8 months old [14] although older animals can also be affected. This neurological disease is associated with a variety of clinical signs, including tremors, circling, bruxism, incoordination and recumbency, followed by convulsions, padding and inevitable death $[15,3,16,17,5]$. Although sporadic cases of meningo-encephalitis by BoHV -5 have been reported in Australia [3,18], Italy [19] and Hungary [20], BoHV-5 infection and disease are more frequent in Argentina and Brazil; where numerous outbreaks have been described in the last decades [16,21-24]. The rare occurrence of BoHV-5 neurological disease in areas where BoHV-1 infection is endemic could be explained by cross-protection induced by BoHV-1 natural infection or vaccination $[25,2,26,27]$.

Restriction endonuclease analysis (REA) has been widely used to compare BoHV-1 isolates [28,29]. It proved to be particularly useful for the differentiation among various ruminant alphaherpesviruses antigenically related to BoHV-1, which show distinct DNA fingerprints [30,31]. Additionally, this technique allows the subtyping of viruses that apparently belong to the same type [28,32].

Traditionally, the differentiation between BoHV-1 and BoHV-5 is based on the clinico- epidemiological characteristics of the outbreaks followed by REA of viral DNA after virus isolation. However, it is not highly precise because BoHV-1 can also be responsible for neurological disease [33,34]. Furthermore, immunoassays using monoclonal antibodies $[4,35,36]$, PCR followed by REA [37], nested PCR [13] and multiplex PCR [38-40] are also available.

Different strains of BoHV-5 were previously classified and designed as BoHV-5 "a"; BoHV-5 "b" and BoHV-5 "non-a, non-b" according to REA $[4,41]$. A subtle antigenic difference was shown between subtypes "a" and "b" [4].

The first outbreak of BoHV-5 in Argentina was described in 1982; when the reference strain A663 was isolated. This viral strain was classified by REA as subtype "b" which has only been described in Argentina so far. Therefore, the aims of this study are to compare and characterize by REA the genomes of Argentinean BoHV-5 isolates obtained from cattle with neurological disease since 1984 until now. Furthermore, we identified the mutation that leads to the change in the restriction pattern of the strain A663. We describe a simple diagnostic method based on PCR-REA system that allows an easy discrimination between BoHV-5 "a" and "b" subtypes.

\section{Results}

Most of the isolates included in this study come from outbreaks that occurred between 1982 and 2007 in Buenos Aires province (Argentina). As summarized in Table 1, most of the field BoHV-5 strains were isolated and

Table 1 Bovine herpesvirus 5 isolates and reference strains grouped in subtypes according to restriction endonuclease analysis

\begin{tabular}{|c|c|c|c|c|}
\hline Subtype & Year & Strain & Sample & Origin and Clinical Signs \\
\hline \multirow[t]{17}{*}{ a } & 1985 & N569 & Brain & Australia - Encephalitis (Ref strain) \\
\hline & & $28(30 / 5)$ & Lung & Argentina - No data \\
\hline & & $136 / 85$ & Brain & Argentina -No data \\
\hline & & $75 / 85$ & Brain & Argentina -No data \\
\hline & 1989 & $67 / 899 \mathrm{H}$ & Ocular Swabs & Balcarce (Buenos Aires, Argentina). Ocular lesions, mouth and prepuce. \\
\hline & & $54 / 89$ & Lung & Tandil (Buenos Aires, Argentina). Respiratory signs, 10\% mortality. \\
\hline & 1999 & Balcarce & Brain & Balcarce (Buenos Aires, Argentina). Encephalitis \\
\hline & & 740 & Brain & Monte (Buenos Aires, Argentina). Encephalitis \\
\hline & & 730 & Brain & Benito Juarez (Buenos Aires, Argentina). Encephalitis. \\
\hline & & 742 & Brain & Coronel Suarez (Buenos Aires, Argentina). Encephalitis. \\
\hline & & 80458 & Brain & Daireux (Buenos Aires, Argentina). Congestion of the brain without malacia. \\
\hline & & 82159 & Brain & La Plata (Buenos Aires, Argentina). Necrosis in both frontal lobes of the brain. \\
\hline & & 81509 & Brain & No data. Brain with malacia in both frontal lobes. \\
\hline & 2000 & 98413 & Brain & Guaminí (Buenos Aires, Argentina). Encephalitis. \\
\hline & 2002 & 15520 & Brain & Santa Fe (Argentina). Encephalitis. \\
\hline & & 16697 & Brain & La Pampa (Argentina). Encephalitis. \\
\hline & 2007 & 72082 & Brain & Monte (Buenos Aires, Argentina). No data. \\
\hline \multirow[t]{2}{*}{$\mathrm{b}$} & 1982 & A663 & Brain & Argentina - Encephalitis (Ref. strain) \\
\hline & 1984 & S-N-59 (166/84) & Brain & Argentina - No data \\
\hline
\end{tabular}


amplified from the brain of cattle affected with encephalitis. The virus was also isolated from ocular swabs and from the lung of animals with respiratory disease. All viruses isolated from tissues of cattle were successfully amplified. PCR analysis allowed the differentiation between BoHV-1 and BoHV-5 based on the size of the PCR products (159 bp for BoHV-5 and 354 bp for BoHV1). All field isolates from cattle were BoHV-5 (figure 1).

Most field isolates (16 out of 17 isolates) showed a BstEII REA pattern similar to the reference strain N569, prototype of BoHV-5a (Figure 2). Only one field strain (S-N-59 (166/84)) presented a REA pattern similar to the Argentinean reference strain A663 prototype of BoHV-5b. The S-N-59 (166/84) was isolated in 1984, one year after the isolation of the strain A663 (Lane 4, Figure 2).

A fragment of $534 \mathrm{pb}$ of the UL27 gene, encoding the BoHV-5 glycoprotein B (gB) from the reference strain of BoHV-5 and seventeen isolates of BoHV-5 were sequenced. A consistent alignment provided by a $500 \mathrm{bp}$ fragment from this gene revealed a point mutation ( $\mathrm{C}$ to $\mathrm{T})$ in the BstEII restriction site of subtype " $\mathrm{b}$ " of BoHV5 , responsible for the variation in the REA pattern. The point mutation is shown in alignment with the reference subtypes of BoHV-5 and the isolates (figure 3 ).

The specific 534-bp PCR product was consistently obtained as a clear electrophoretic band from all isolates and reference strains of BoHV-5. The digestion of the PCR products with the restriction enzyme BstEII generated distinct restriction patterns depending on the origin of the amplified viral DNA (BoHV-5 "a" or "b" subtypes): 152 and 382 bp for BoHV-5 "a" subtype and 534 bp for BoHV-5 b (Figure 4)

\section{Discussion}

A high seroprevalence for BoHV-1 was reported in Argentina [42]. By now, the proportion of this percentage

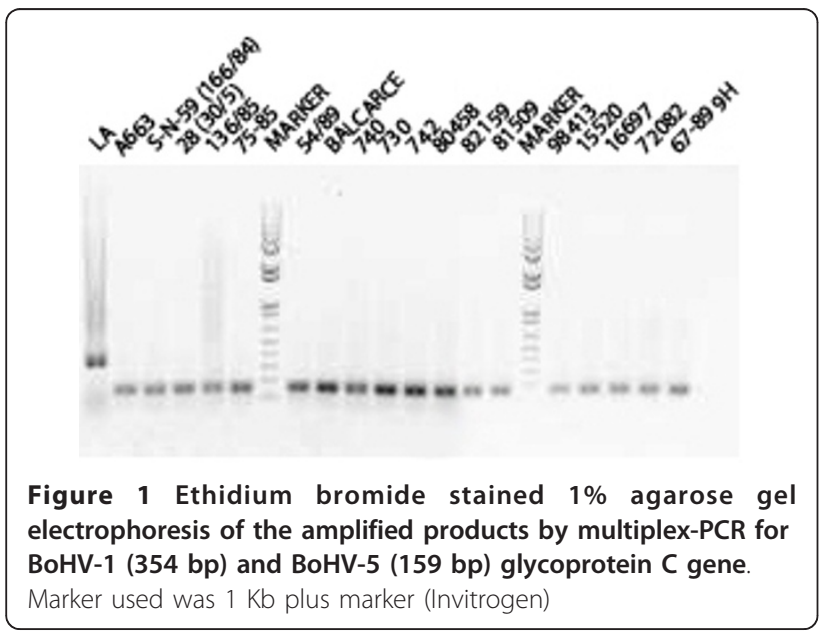

that can be attributed to BoHV-5 is unknown since diagnostic tests do not differentiate between anti- BoHV-1 and -BoHV-5 antibodies [10,26]. Although the clinical manifestations of BoHV-1 and 5 are slightly different, this is not sufficient to allow a precise distinction between virus species. Furthermore, cases of meningoencephalitis can also be consequence of BoHV-1 infection [43]. Neighboring countries have reported the circulation of BoHV-5 subtypes "a" and non-"a" non -"b" although Argentina was the first and the only country to report the isolation of a BoHV-5 strain belonging to subtype "b" [41,44].

It has been reported that some outbreaks attributed to the subtype "a" group occurred with respiratory signs in the absence of nervous manifestations (67/89 9H, 54/ 89). Indeed, in diseased animals, virus infection is not restricted to the central nervous system [21]. Further studies will be required to determine why these BoHV-5 isolates were non-neuropathogenic under these natural conditions.

Several outbreaks occurring between 1981 and 1984, mainly in the central region of Argentina, were determined to be caused by BoHV-5 (9 out of 10 isolates) [21]. In many cases there were no records of morbidity and mortality, except for the outbreak in which the strain A663 was isolated, where 15\% (81 out of 540) animals died. Ten percent of the isolates recovered during this period showed slower growth and smaller plaques in tissue culture than the Jura strain of BoHV-1. In this report, we also observed one isolate of BoHV-5 with poor growth in cell culture (1/17), which was classified as subtype "b". This field strain was isolated in 1984 from a meningo-encephalitis outbreak in Arroyo Corto, Saavedra district, located southwest of the Buenos Aires province; the affected herd consisted of 158 bovines; with only one fatality case. This farm had presented a similar outbreak in July-August 1983. Interestingly, this strain affected older animals (18 to 26 months) than the historical case attributed to A663 (5 to 18 months).

According to our study, it is evident that in Argentina both subtypes "a" and "b" circulated for some time and, apparently the circulation of subtype "a" is more recent. As in Brazil, the co-circulation of subtypes "a" and non "a", non "b" was reported [41], further studies are required to determine whether subtype non "a" non " $b$ " is present or will appear in Argentina and whether subtype "b" will definitely disappeared.

In this study, we were also able to determine the region of the subtype "b" genome which is responsible for the different BstEII restriction patterns. The $\mathrm{C}$ - $\mathrm{T}$ substitution observed in the gene encoding $\mathrm{gB}$, a glycoprotein that is involved in the entry and cell-to-cell spread of virus [45-48] did not introduce an amino-acid change. The digestion of the PCR products with the restriction 


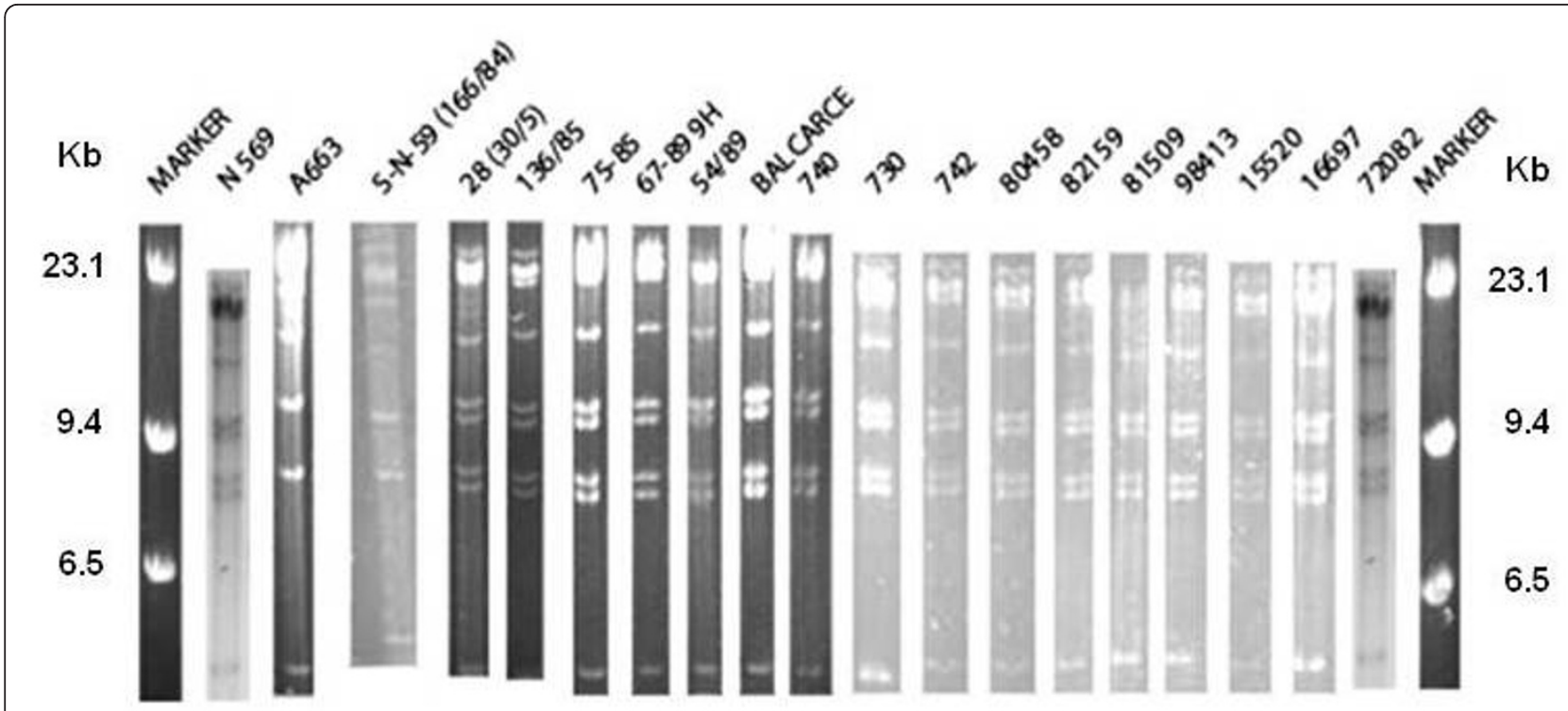

Figure 2 BstEll restriction endonuclease profiles of the isolates and the reference strains. Marker: molecular weight marker (lambda Hind III, Invitrogen).

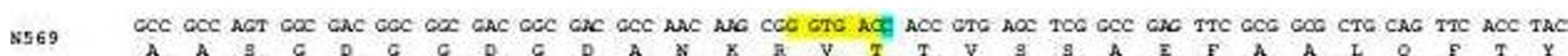

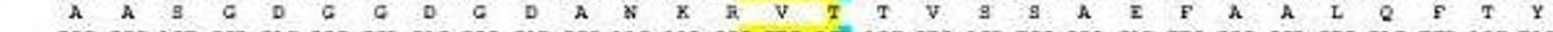

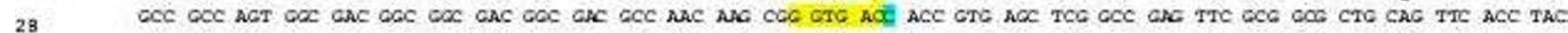

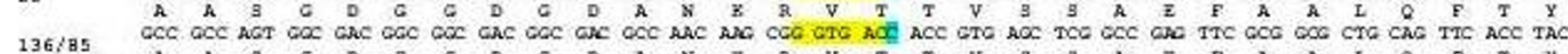

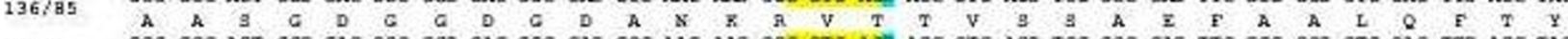

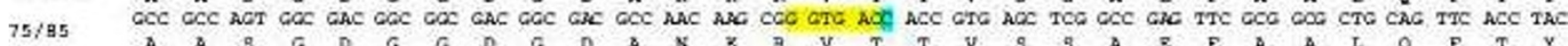

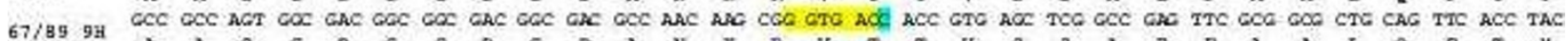

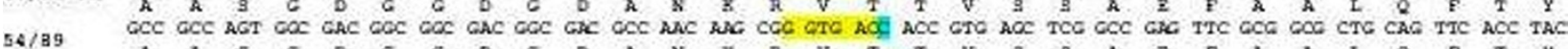

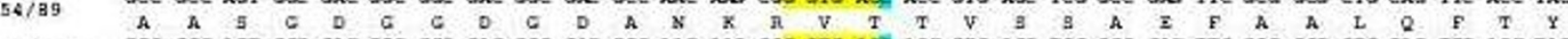

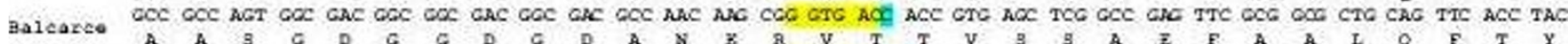

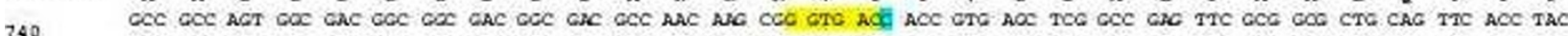
$\begin{array}{lllllllllllllllllllllllllllllll}A & A & B & G & D & G & G & D & G & D & A & X & X & \pi & V & T & T & V & g & g & A & E & F & A & A & L & Q & F & T & Y\end{array}$

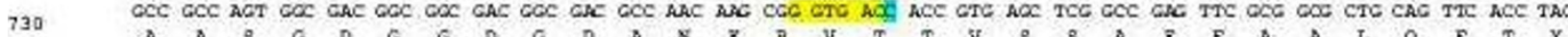

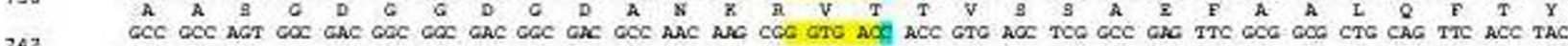

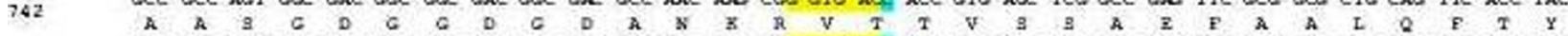

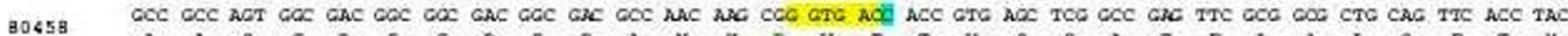

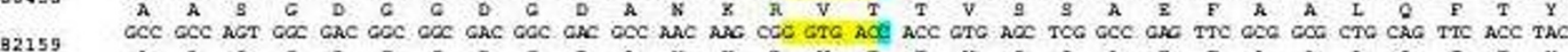
82159 A A B C D G G D G D A K K R V T T V A B A E F A A I Q E T Y

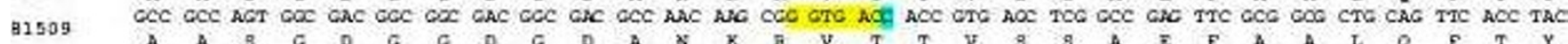

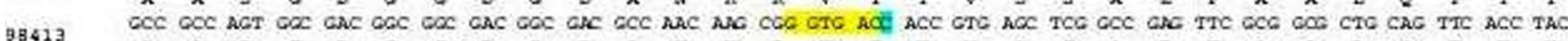

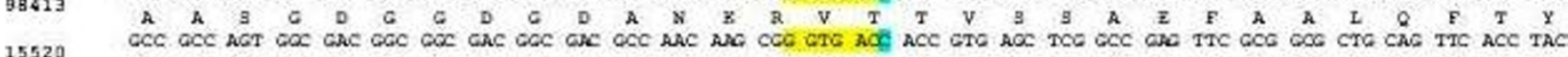
15520 A A B G D G G D G D A B R R V T T V B B A E E A A L Q E T Y

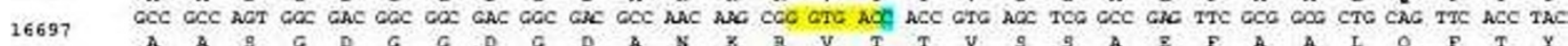

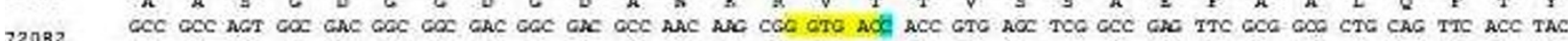

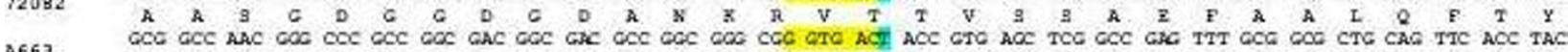

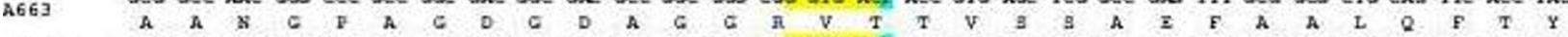

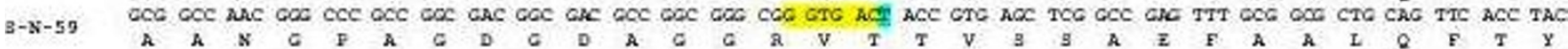

Figure 3 Localization of the point mutation in the BoHV-5 subtype "b". Multiple nucleotide alignment of 87 bp of the UL27 region surrounding the mutation; the restriction site and the mutation are highlighted. Multiple amino-acid alignment of the gB region surrounding the mutation; it is located in the third position (58295 nt position of the genome AY261359) of a threonine codon present in the three strains analyzed, indicating that the mutation does not produce an amino acid change. 


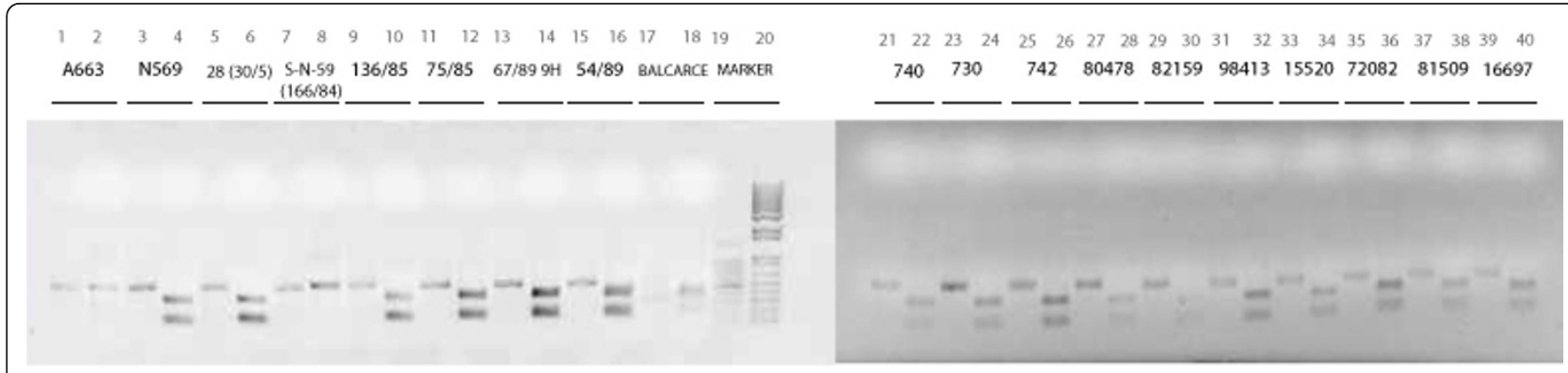

Figure 4 PCRs amplicons before and after digestion with BstEll of all isolates andreference strains. Markers used: lane 19) 100 bp DNA Ladder (Promega); lane 20) $1 \mathrm{~Kb}$ plus marker (Invitrogen). In gel we added e bar that includes the lines with the undigested PCR product and digested PCR product for each virus. The left line of each virus: the amplicon was digested with the enzyme BstEll.

enzyme BstEII allowed the easy discrimination between "a" and "b" subtypes The diagnostic system based on PCR products has been tested on seventeen isolates and references strains, however before considering the general applicability of this assay it will be necessary to analyze more samples of all BoHV-5 subtypes.

The fragment amplified by PCR shows significant differences at the amino-acid level when compared with the published sequence of this portion of the gene. It will be necessary to conduct further studies to prove whether the changes present in the gB gene of subtype "b" viruses can be related to a specific pattern of virus spread and properties, as observed by Schudel and collaborators [21] regarding the formation of smaller plaques in cell culture and slower growth kinetics with respect to the reference virus.

A further epidemiological study would be required to investigate why the circulation of subtype "b" viruses is restricted to Argentina and why it was only observed in 1982 and 1984. It would also be important to determine whether these isolates exhibit a distinct behavior in vivo.

\section{Conclusion}

According to our knowledge, this is the first report on the circulation of BoHV-5 subtype "a" in Argentina. We determined that a mutation in the $\mathrm{gB}$ gene is responsible for the difference in the restriction pattern between subtypes "a" and "b". According to the number of samples analyzed, most of the field isolates - including the current ones - belong to subtype "a". Subtype "b" was only isolated during a transient period in 1982 and 1984, and apparently is no longer circulating in the country.

\section{Methods}

\section{Viruses and cells}

BoHV-5 strains were obtained by isolation from samples of naturally infected animals. The virus isolates used in this study are shown in Table 1 . They were collected from our and other laboratories across Argentina. All viruses were propagated in Madin Darby Bovine Kidney
(MDBK) cells grown in Eagle's minimal essential medium (E-MEM) supplemented with $2 \%$ fetal bovine serum (FBS) [49]. The strains N569 and A663 representative of BoHV-5 "a" and BoHV-5 "b" subtypes, respectively, were used as reference viruses $[4,41,50,51]$.

\section{Viral DNA extraction}

Viruses were inoculated in tissue culture flaks $\left(175 \mathrm{~cm}^{2}\right)$ with nearly confluent, overnight grown MDBK monolayer, at a multiplicity of infection of 0.1 and incubated at $37^{\circ} \mathrm{C}$ and $5 \% \mathrm{CO} 2$. When cytopathic effect reached $80-90 \%$ ( $48 \mathrm{~h}$ ), the culture medium was clarified by low speed centrifugation and supernatant centrifuged at $100,000 \times g$ for $1 \mathrm{~h}$. The viral pellet was re-suspended in buffer TE with 1\% NP40 (10 mM Tris; 1mM EDTA; pH 8; $1 \% \mathrm{NP} 40)$ and incubated at $56^{\circ} \mathrm{C}$ in thermostatic bath. The suspension was ultra-centrifuged in a saccharose gradient at 100,000 $\times g$. The viral pellet was re-suspended in TE (10 mM Tris, 1 mM EDTA; pH 8) and treated with $10 \%$ sodium dodecyl sulfate (SDS) and $0.1 \mathrm{mg} / \mathrm{ml}$ proteinase $\mathrm{K}$ for $1 \mathrm{~h}$ at $60^{\circ} \mathrm{C}$. After digestion, the viral DNA was extracted twice with an equal volume of phenol:chloroform:isoamyl alcohol $(25: 24: 1)$ and precipitated with 2 volumes of cold ethanol and $0.3 \mathrm{M} \mathrm{NaCl}$. The pellet obtained was rinsed with $600 \mu \mathrm{l}$ of $70 \%$ ethanol, dried and re suspended in $50 \mu \mathrm{l}$ of nuclease free water and stored at $-20^{\circ} \mathrm{C}$ until use. DNA concentration and purity was measured by BioPhotometer (Eppendorf Scientific, Westbury, $\mathrm{NY}$ ) at 260 and $280 \mathrm{~nm}$.

\section{Differential PCR assay}

The PCR designed by Claus and collaborators [39] was carried out with some modifications. The primers were B1 specific for BoHV-1 (5-CAA CCG AGA CGG AAA GCT CC-3_nt 185-204); B5 specific for BoHV-5 (5CGG ACG AGA CGC CCT TGG-3_nt 322-339) and consensus primer designated Bcon (5-AGT GCA CGT ACA GCG GCT CG-3_nt 519-538). The amplification product was $159 \mathrm{bp}$ from BoHV-5 and $354 \mathrm{bp}$ from BoHV-1 (glycoprotein C gene). The multiplex-PCR was 
prepared in a reaction containing $50 \mathrm{ng}$ of extracted DNA and $12.5 \mu \mathrm{l}$ of mix-PCR consisting of $0.4 \mathrm{pmol}$ of each primer (B1, B5, and Bcon); $1.5 \mathrm{mMol}$ dNTPs (Invitrogen TM Life Technologies, USA); 2.5 units of Taq DNA Polymerase (Invitrogen TM Life Technologies, USA); 1X PCR buffer (20 mM Tris- $\mathrm{HCl}$ pH 8.4, $50 \mathrm{mM}$ $\mathrm{KCl}) ; 1.5 \mathrm{mM} \mathrm{MgCl}_{2}$ and ultrapure sterile water to a final volume of $12.5 \mu \mathrm{l}$. Amplification reactions were performed in a thermocycler (Biometra TRIO - Thermoblock) under the following conditions: one step of $10 \mathrm{~min}$ at $96^{\circ} \mathrm{C}$ followed by 25 cycles of $1 \mathrm{~min}$ at $96^{\circ} \mathrm{C} ; 1 \mathrm{~min}$ at $58^{\circ} \mathrm{C} ; 1 \mathrm{~min}$ at $72^{\circ} \mathrm{C}$ and one last extension step of 10 $\min$ at $72^{\circ} \mathrm{C}$. The products were analyzed on $1 \%$ agarose gel electrophoresis, stained with ethidium bromide $(0.5$ $\mu \mathrm{g} / \mathrm{ml}$ ) in TBE buffer $\mathrm{pH} 8.4$ (89 mM Tris, $89 \mathrm{mM}$ boric acid, 2 mM EDTA) and visualized under UV light.

\section{Restriction endonuclease analysis (REA)}

Four $\mu \mathrm{g}$ of viral DNA from each strain were cleaved with the restriction enzyme BstEII under the conditions recommended by the manufacturer (Promega). The digestion products were separated by electrophoresis on a $0.7 \%$ agarose gel at $50 \mathrm{~V}$ O.N. using TBE buffer $\mathrm{pH}$ 8.4 ( $89 \mathrm{mM}$ Tris, $89 \mathrm{mM}$ boric acid, $2 \mathrm{mM}$ EDTA). The gels were stained with ethidium bromide $(1 \mu \mathrm{g} / \mu \mathrm{l})$ and photographed under UV light.

\section{UL27 PCR assay}

Primers were designed based on the published sequence of BoHV-5 (Genbank accession number: AY261359) [1] (UL27F: 5-CTG-GCA-CGA-TCG-AAC-GGC-A-3 nt 58116 and UL27R: 5-AGC-AGC-TCG-TTG-TCC-TCGC-3 nt 58651). A study conducted in silico with bioinformatic tools showed that the site that determines a type " $b$ " pattern is included in the open reading frame of the glycoprotein B (UL27). DNA sequence analysis to locate the discriminative mutant region between BoHV$5 \mathrm{a}$ and BoHV-5b within the UL27 target gen was performed using Vector NTI Suite version 8.0 (InforMax Inc-Invitrogen, Merelbeke, Belgium). The assay was performed with purified DNA from strains of different subtypes. Amplification was carried out in a $50 \mu$ l reaction mix containing $5 \mathrm{ng}$ of template DNA, Taq DNA polymerase buffer (New England Biolabs, NEB, Ipswich, MA, USA), $2 \mathrm{mM} \mathrm{MgCl}_{2}, 6 \%$ DMSO, $200 \mu \mathrm{M}$ dNTPs, $0.3 \mu \mathrm{M}$ of both forward and reverse primers and $1 \mathrm{U}$ TaqDNA polymerase (NEB). Annealing temperatures were optimized for each primer pairs. PCR products were confirmed by electrophoresis on a $2 \%$ agarose gel.

\section{Digestion of amplified product with BstEIl (PCR-REA assay)}

The purified PCR products were digested with the restriction enzyme BstEII under the conditions recommended by the manufacturer (Promega). The resulting products were separated by electrophoresis in $1 \%$ agarose gels and were visualized by ethidium bromide staining under UV light.

\section{Sequences analysis}

Amplified products were purified using Illustra GFX ${ }^{\mathrm{TM}}$ PCR, DNA and gel band purification kit (GE Healthcare, Diegem, Belgium). The quality of all DNA preparations was evaluated by agarose gel electrophoresis. Sequencing reactions were performed with BigDye Terminator v3.0 kit (Applied Biosystems, Lennik, Belgium) and analyzed with ABI Prism 3730 DNA Analyzer (Applied Biosystems). Each product was sequenced twice in both directions using forward and reverse primers. The deduced nucleotide and amino-acid sequences were edited; aligned and analyzed with BioEdit version 7.0.5.3 [52].

\section{Acknowledgements}

The authors wish to thank Daniela Cianfrini (INTA) for help to draft the manuscript and Domnique Ziant and Thomas Delwiche for their excellent technical assistance (university of Liege, Belgium) for kindly providing some primers. This work was supported by FNRS and CONICET. SM is fellow of the National Agency for Science and Technical (Argentina).

\section{Author details}

${ }^{1}$ Virology Institute, Veterinary and Agricultural Science Research Centre (CICVyA), National Institute of Agricultural Technology (INTA), N. Repetto y Los Reseros S/N, CC25 (B1712WAA), Castelar, Buenos Aires, Argentina.

${ }^{2}$ Virology and Viral Diseases, Department of Infectious and Parasitic Diseases, Faculty of Veterinary Medicine, University of Liège, Boulevard de Colonster, 20, B43b, B-4000 Liège, Belgium. ${ }^{3}$ Consejo Nacional de Investigaciones Científicas y Tecnológicas (CONICET), Rivadavia 1917 (C1033AAJ), Ciudad Autónoma de Buenos Aires, Argentina. ${ }^{4}$ Laboratorio Azul, Av. 25 de Mayo 479/485 (7300), Azul, Buenos Aires, Argentina. ${ }^{5}$ National University of the Center of Buenos Aires Province, Faculty of Veterinary Medicine, Department of Animal Health and Preventive Medicine, Virology Area, Paraje Arroyo Seco s/n, Tandil (7000), Buenos Aires, Argentina.

\section{Authors' contributions}

SM and SR designed the experiments, analysed the data and drafted the manuscript together. SM performed the experiments. ML, AO, JBV, GC, NF and MD gently surrendered the field isolates. BM, JT and ET participated in the molecular genetic studies and interpretation of data. SP and MP helped to draft the manuscript. FL participated in the amplification of some field isolates. All authors read and approved the final manuscript.

\section{Competing interests}

The authors declare that they have no competing interests.

Received: 5 July 2010 Accepted: 7 February 2011

Published: 7 February 2011

\section{References}

1. Delhon G, Moraes MP, Lu Z, Afonso CL, Flores EF, Weiblen R, Kutish GF, Rock DL: Genome of bovine herpesvirus 5. Journal of virology 2003, 77(19):10339-10347.

2. Thiry J, Tempesta M, Camero M, Tarsitano E, Bellacicco AL, Thiry E, Buonavoglia C: A live attenuated glycoprotein $E$ negative bovine herpesvirus 1 vaccine induces a partial cross-protection against caprine herpesvirus 1 infection in goats. Veterinary microbiology 2006, 113(34):303-308.

3. Bagust TJ, Clark L: Pathogenesis of meningo-encephalitis produced in calves by infectious bovine rhinotracheitis herpesvirus. Journal of comparative pathology 1972, 82(4):375-383. 
4. Metzler AE, Schudel AA, Engels M: Bovine herpesvirus 1: molecular and antigenic characteristics of variant viruses isolated from calves with neurological disease. Archives of virology 1986, 87(3-4):205-217.

5. Meyer G, Lemaire M, Ros C, Belak K, Gabriel A, Cassart D, Coignoul F, Belak S, Thiry E: Comparative pathogenesis of acute and latent infections of calves with bovine herpesvirus types 1 and 5. Archives of virology 2001, 146(4):633-652.

6. Del Medico Zajac MP, Ladelfa MF, Kotsias F, Muylkens B, Thiry J, Thiry E, Romera SA: Biology of bovine herpesvirus 5. Vet J 2010, 184(2):138-145.

7. Carrillo BJ, Pospischil A, Dahme E: Pathology of a bovine viral necrotizing encephalitis in Argentina. Zentralblatt fur Veterinarmedizin Reihe B Journal of veterinary medicine 1983, 30(3):161-168.

8. Perez SE, Bretschneider G, Leunda MR, Osorio EA, Flores EF, Odeon AC: Primary infection, latency, and reactivation of bovine herpesvirus type 5 in the bovine nervous system. Veterinary pathology 2002, 39(4):437-444.

9. Vogel FS, Caron L, Flores EF, Weiblen R, Winkelmann ER, Mayer SV, Bastos RG: Distribution of bovine herpesvirus type 5 DNA in the central nervous systems of latently, experimentally infected calves. Journal of clinical microbiology 2003, 41(10):4512-4520.

10. Whetstone CA, Seal BS, Miller JM: Variability occurs in the inverted repeat region of genomic DNA from bovine herpesvirus 1 respiratory, genital and bovine herpesvirus 5 encephalitic isolates. Veterinary microbiology 1993, 38(1-2):181-189.

11. Del Medico Zajac MP, Puntel M, Zamorano PI, Sadir AM, Romera SA: BHV-1 vaccine induces cross-protection against BHV-5 disease in cattle. Research in veterinary science 2006, 81(3):327-334.

12. Belknap EB, Collins JK, Ayers VK, Schultheiss PC: Experimental infection of neonatal calves with neurovirulent bovine herpesvirus type 1.3. Veterinary pathology 1994, 31(3):358-365.

13. Ashbaugh SE, Thompson KE, Belknap EB, Schultheiss PC, Chowdhury S, Collins JK: Specific detection of shedding and latency of bovine herpesvirus 1 and 5 using a nested polymerase chain reaction. $J$ Vet Diagn Invest 1997, 9(4):387-394.

14. Bulach DM, Studdert MJ: Comparative genome mapping of bovine encephalitis herpesvirus, bovine herpesvirus 1 , and buffalo herpesvirus. Archives of virology 1990, 113(1-2):17-34

15. Hall WT, Simmons GC, French EL, Snowdon WA, Asdell M: The pathogenesis of encephalitis caused by the infectious bovine rhinotracheitis virus. Australian veterinary journal 1966, 42(7):229-237.

16. Carrillo BJ, Ambrogi A, Schudel AA, Vazquez M, Dahme E, Pospischil A: Meningoencephalitis caused by IBR virus in calves in Argentina. Zentralblatt fur Veterinarmedizin Reihe B Journal of veterinary medicine 1983, 30(5):327-332.

17. Silva MS, Brum MC, Loreto EL, Weiblen R, Flores EF: Molecular and antigenic characterization of Brazilian bovine herpesvirus type 1 isolates recovered from the brain of cattle with neurological disease. Virus research 2007, 129(2):191-199.

18. French EL: A specific virus encephalitis in calves: isolation and characterization of the causal agent. Aust Vet J 1962, 38:216-221.

19. Moretti B, Orfei Z, Mondino G, Persechino A: [Isolation of the Infectious Bovine Rhinotracheitis (lbr) Virus in Italy. (Preliminary Note)]. Nuovi annali d'igiene e microbiologia 1964, 15:18-22.

20. Bartha A, Hajdu G, Aldasy P, Paczolay G: Occurrence of encephalitis caused by infectious bovine rhinotracheitis virus in calves in hungary. Acta veterinaria Academiae Scientiarum Hungaricae 1969, 19(2):145-151.

21. Schudel AA, Carrillo BJ, Wyler R, Metzler AE: Infections of calves with antigenic variants of bovine herpesvirus 1 (BHV-1) and neurological disease. Zentralblatt fur Veterinarmedizin Reihe B Journal of veterinary medicine 1986, 33(4):303-310.

22. Weiblen R, de Barros CS, Canabarro TF, Flores IE: Bovine meningoencephalitis from IBR virus. The Veterinary record 1989, 124(25):666-667.

23. Salvador SC, Lemos RAA, Riet-Correa F, Roehe PM, Osorio ALAR: Meningoencefalite em bovinos causada por herpesvirus bovino 5 no Mato Groso do Sul e Sao Paulo. Pesq Vet Bras 1998, 18:76-63.

24. Silva AM, Weiblen $\mathrm{R}$, Irigoyen $\mathrm{LF}$, Roehe $\mathrm{PM}$, Sur HJ, Osorio FA, Flores EF: Experimental infection of sheep with bovine herpesvirus type-5 (BHV-5): acute and latent infection. Veterinary microbiology 1999, 66(2):89-99.

25. d'Offay JM, Ely RW, Baldwin CA, Whitenack DL, Stair EL, Collins JK: Diagnosis of encephalitic bovine herpesvirus type 5 (BHV-5) infection in cattle: virus isolation and immunohistochemical detection of antigen in formalin-fixed bovine brain tissues. J Vet Diagn Invest 1995, 7(2):247-251.
26. Del Medico Zajac MP, Puntel M, Zamorano PI, Sadir AM, Romera SA: BHV-1 vaccine induces cross-protection against BHV-5 disease in cattle. Research in veterinary science 2006, 81(3):327-334.

27. Del Medico Zajac MP, Romera SA, Ladelfa MF, Kotsias F, Thiry J, Ziant D, Meurens F, Keil GM, Thiry E, Muylkens B: Characterization of interspecific recombinants generated from closely related bovine herpesviruses 1 and 5 through multiple PCR sequencing assays. Journal of virological methods 2009, 161(1):75-83.

28. Engels M, Steck F, Wyler R: Comparison of the genomes of infectious bovine rhinotracheitis and infectious pustular vulvovaginitis virus strains by restriction endonuclease analysis. Archives of virology 1981, 67(2):169-174

29. Gregersen JP, Pauli G, Ludwig H: Bovine herpesvirus 1: differentiation of IBR- and IPV-viruses and identification and functional role of their major immunogenic components. Archives of virology 1985, 84(1-2):91-103.

30. Engels M, Gelderblom H, Darai G, Ludwig H: Goat herpesviruses: biological and physicochemical properties. The Journal of general virology 1983, 64(Pt 10):2237-2247.

31. Brake F, Studdert MJ: Molecular epidemiology and pathogenesis of ruminant herpesviruses including bovine, buffalo and caprine herpesviruses I and bovine encephalitis herpesvirus. Australian veterinary journal 1985, 62(10):331-334.

32. Misra V, Babiuk LA, Darcel CL: Analysis of bovine herpes virus-type 1 isolates by restriction endonuclease fingerprinting. Archives of virology 1983, 76(4):341-354.

33. Sreenivasa BP, Natarjan C, Rasool TJ: Restriction endonuclease analysis of DNA from Indian isolates of bovine herpesvirus 1. Acta virologica 1996, 40(5-6):315-318.

34. Pidone $\mathrm{CL}$, Galosi CM, Echeverria MG, Nosetto EO, Etcheverrigaray ME: Restriction endonuclease analysis of BHV-1 and BHV-5 strains isolated in Argentina. Zentralblatt fur Veterinarmedizin Reihe $B$ Journal of veterinary medicine 1999, 46(7):453-456.

35. Keuser V, Schynts F, Detry B, Collard A, Robert B, Vanderplasschen A, Pastoret PP, Thiry E: Improved antigenic methods for differential diagnosis of bovine, caprine, and cervine alphaherpesviruses related to bovine herpesvirus 1. Journal of clinical microbiology 2004, 42(3):1228-1235

36. Thiry J, Tempesta M, Camero M, Tarsitano E, Muylkens B, Meurens F, Thiry E, Buonavoglia C: Clinical protection against caprine herpesvirus 1 genital infection by intranasal administration of a live attenuated glycoprotein $\mathrm{E}$ negative bovine herpesvirus 1 vaccine. BMC veterinary research 2007, 3:33.

37. Ros C, Belák S: Studies of genetic relationships between bovine, caprine, cervine, and rangiferine alphaherpesviruses and improved molecular methods for virus detection and identification. J Clin Microbiol 1999, 37:1247-1253.

38. Alegre $M$, Nanni $M$, Fondevila N: Development of a multiplex polymerase chain reaction for the differentiation of bovine herpesvirus- 1 and -5 . Journal of veterinary medicine 2001, 48(8):613-621.

39. Claus MP, Alfieri AF, Folgueras-Flatschart AV, Wosiacki SR, Medici KC, Alfieri AA: Rapid detection and differentiation of bovine herpesvirus 1 and 5 glycoprotein $\mathrm{C}$ gene in clinical specimens by multiplex-PCR. Journal of virological methods 2005, 128(1-2):183-188

40. Thiry J, Widen F, Gregoire F, Linden A, Belak S, Thiry E: Isolation and characterisation of a ruminant alphaherpesvirus closely related to bovine herpesvirus 1 in a free-ranging red deer. BMC veterinary research 2007, 3:26.

41. D'Arce RC, Almeida RS, Silva TC, Franco AC, Spilki F, Roehe PM, Arns CW: Restriction endonuclease and monoclonal antibody analysis of Brazilian isolates of bovine herpesviruses types 1 and 5 . Veterinary microbiology 2002, 88(4):315-324.

42. Odeón AC, Spath EJA, Paloma EJ, Leunda MR, Fernandez Sainz IJ, Perez SE, Kaiser GG, Draghi MG, Cetrá BM, Cano A: Seroprevalencia de ladiarrea viral bovina, herpesvirus bovino y virus sincicial respiratorioen Argentina. Revista de Medicina Veterinaria 2001, 82:216-220, (Argentina).

43. Roels S, Charlier G, Letellier C, Meyer G, Schynts F, Kerkhofs P, Thiry E, Vanopdenbosch E: Natural case of bovine herpesvirus 1 meningoencephalitis in an adult cow. The Veterinary record 2000, 146(20):586-588

44. Esteves PA, Dellagostin OA, Pinto LS, Silva AD, Spilki FR, Ciacci-Zanella JR, Hubner SO, Puentes R, Maisonnave J, Franco AC: Phylogenetic comparison of the carboxy-terminal region of glycoprotein $\mathrm{C}(\mathrm{gC})$ of bovine 
herpesviruses (BoHV) 1.1, 1.2 and 5 from South America (SA). Virus research 2008, 131(1):16-22.

45. Kopp A, Blewett E, Misra V, Mettenleiter TC: Proteolytic cleavage of bovine herpesvirus 1 (BHV-1) glycoprotein $\mathrm{gB}$ is not necessary for its function in BHV-1 or pseudorabies virus. Journal of virology 1994, 68(3):1667-1674.

46. Cai WH, Gu B, Person S: Role of glycoprotein B of herpes simplex virus type 1 in viral entry and cell fusion. Journal of virology 1988 62(8):2596-2604

47. Cai WZ, Person S, DebRoy C, Gu BH: Functional regions and structural features of the gB glycoprotein of herpes simplex virus type 1. An analysis of linker insertion mutants. Journal of molecular biology 1988, 201(3):575-588.

48. Navarro D, Paz P, Pereira L: Domains of herpes simplex virus I glycoprotein B that function in virus penetration, cell-to-cell spread, and cell fusion. Virology 1992, 186(1):99-112.

49. Romera SA, Hilgers LA, Puntel M, Zamorano PI, Alcon VL, Dus Santos MJ, Blanco Viera J, Borca MV, Sadir AM: Adjuvant effects of sulfolipocyclodextrin in a squalane-in-water and water-in-mineral oil emulsions for BHV-1 vaccines in cattle. Vaccine 2000, 19(1):132-141.

50. Metzler AE, Matile H, Gassmann U, Engels M, Wyler R: European isolates of bovine herpesvirus 1: a comparison of restriction endonuclease sites, polypeptides, and reactivity with monoclonal antibodies. Archives of virology 1985, 85(1-2):57-69.

51. Roizmann B, Desrosiers RC, Fleckenstein B, Lopez C, Minson AC, Studdert MJ: The family Herpesviridae: an update. The Herpesvirus Study Group of the International Committee on Taxonomy of Viruses. Archives of virology 1992, 123(3-4):425-449.

52. Hall TA: BioEdit: a user-friendly biological sequence alignment editor and analysis program for Windows 95/98/NT. Nucl Acids Symp Ser 1999, 41:95-98.

doi:10.1186/1746-6148-7-8

Cite this article as: Maidana et al:: Characterization of BoHV-5 field strains circulation and report of transient specific subtype of bovine herpesvirus 5 in Argentina. BMC Veterinary Research 2011 7:8.

\section{Submit your next manuscript to BioMed Central} and take full advantage of:

- Convenient online submission

- Thorough peer review

- No space constraints or color figure charges

- Immediate publication on acceptance

- Inclusion in PubMed, CAS, Scopus and Google Scholar

- Research which is freely available for redistribution

Submit your manuscript at www.biomedcentral.com/submit
Biomed Central 